\title{
A REVISION OF ATTENUATION RELATIONSHIPS FOR MODIFIED MERCALLI INTENSITY IN NEW ZEALAND EARTH- QUAKES
}

\author{
D. J. Dowrick'
}

SUMMARY

\begin{abstract}
This study of attenuation of Modified Mercalli intensity in New zealand earthquakes used a carefully selected set of isoseismal maps from 30 events with magnitudes ranging from $M_{L}=5.0$ to $M_{S}$ $=7.8$, and depths ranging from very shallow to $65 \mathrm{~km}$. A completely revised set of magnitudes was used. A two-step stratified regression analysis was used to evaluate the coefficients of the expression for intensity
\end{abstract}

$$
I=a+b M+c r+d \log _{10} r
$$

\begin{abstract}
where $r$ is the mean slope radius corresponding to the distance from the isoseismal to the centroid of the fault rupture surface. The resulting expressions model events of all depths very well, and completely revise the attenuation curves of earlier work done in the 1970's in which depth was not taken into account. The earlier proposals for regional variations in attenuation were not substantiated, the apparent differences for most of the country being explained by the effects of depth and source mechanism rather than path characteristics. The attenuation character of the Central Volcanic Region and Fiordland remain to be properly established. Attenuation of intensity in New Zealand was found to be very similar to that for Turkey, the two regions being dominated by strike-slip faulting.
\end{abstract}

1

\section{INTRODUCTION}

The subjective felt intensity scales remain a valuable, indeed necessary, measure of strength of ground shaking in earthquakes despite the growth in numbers of strong-motion accelerographs in recent decades. For many years it has been the practice in New Zealand to use the Modified Mercalli (MM) scale, slightly adapted in 1965 to suit New Zealand conditions as described by Eiby $[1,2]$.

The attenuation of MM intensity in New Zealand earthquakes was investigated in the mid-1970's by Smith $[3,4]$ and less comprehensively by Walley [5]. Some subsequent earthquakes have suggested that Smith's attenuation models needed to be reviewed, in particular with specific examination of the effects of depth and source mechanism, and a review of the magnitudes of the events in the data set. In recent years it had become obvious that the magnitudes of New Zealand's larger

Department of Scientific and Industrial Research, Lower Hutt, New Zealand (Member, NZNSEE) earthquakes needed to be re-assessed on a consistent basis. This necessary first step has recently been completed using the surface-wave scale $[6,7]$. In addition the New Zealand Seismological observatory had revised the estimated local magnitude $\mathrm{M}_{\mathrm{T}}$ for most of the events of interest since 1956, as reported elsewhere [6]. Together these newly available $M_{S}$ and $M_{I}$ values differ in all but three cases from the values available to Smith.

The attenuation of intensity, I, may be expressed in the following form

$$
I=\mathrm{a}+\mathrm{bM}+\mathrm{cr}+\mathrm{d} \log _{10} \mathrm{r}
$$

where $a, b, c, d$ are coefficients, $M$ is magnitude, and $r$ is the mean radius (in $\mathrm{km}$ ) of the isoseismal for intensity $I$. Here $r$ is taken as the distance to the effective energy centre at effective depth $h_{e}$ defined later.

Equation (1) is a form of expression previously used for attenuation of intensity, eg Ambraseys' study $[8,9]$ of earthquakes in Turkey, or for the attenuation of peak ground acceleration, $a_{\max }$, where $\log a_{\max }$ is substituted for $I$, as 
in Joyner and Boore's study [10] of Californian ground motion recordings.

\section{EVENTS STUDIED}

For this study the basic data were selected isoseismal maps of events for which instrumentally determined (ie 20th century) magnitudes were available. The maps came from various sources, ie $\mathrm{NZ}$ Seismological observatory annual reports, papers on specific earthquakes [Refs 11-17], and unpublished maps prepared by G A Eiby of the NZ Seismological observatory. The isoseismals had to be reasonably complete and be adequately supported by local intensity observations. At least four isoseismals per event were desirable for establishing the shape of the attenuation curve over as great a distance as possible.
The mean radius $\overline{\mathrm{r}}$ for any given isoseismal was found as the average of the radii along 16 points of the compass as shown in Figure 1 in relation to the isoseismals for the 1968 Inangahua earthquake of $\mathrm{M}_{S}=7.4$. This map illustrates the difficulty of determining reliable values of $\bar{r}$ for New

Zealand earthquakes. Because the land mass is narrow, some of the isoseismals are incomplete on most event maps. Incomplete isoseismals were used only if the rest of the map was complete enough for missing sectors of isoseismals and the effective centre of the isoseismal pattern to be inferred with reasonable confidence. This meant that the inner isoseismals had to be reasonably well determined over a sector of the compass of at least $180^{\circ}$. In Figure 1 the three inner isoseismals are complete and the general pattern suggests an axis of



FIGURE 1 ISOSEISMAL MAP OF 1968 MAY 23 INANGAHUA EARTHOUAKE (FROM REF. 18), SHOWING TEMPLATE IN POSITION FOR MEASURING ISOSEISMAL RADII AT $22.5^{\circ}$ DIRECTIONAL INTERVALS. 


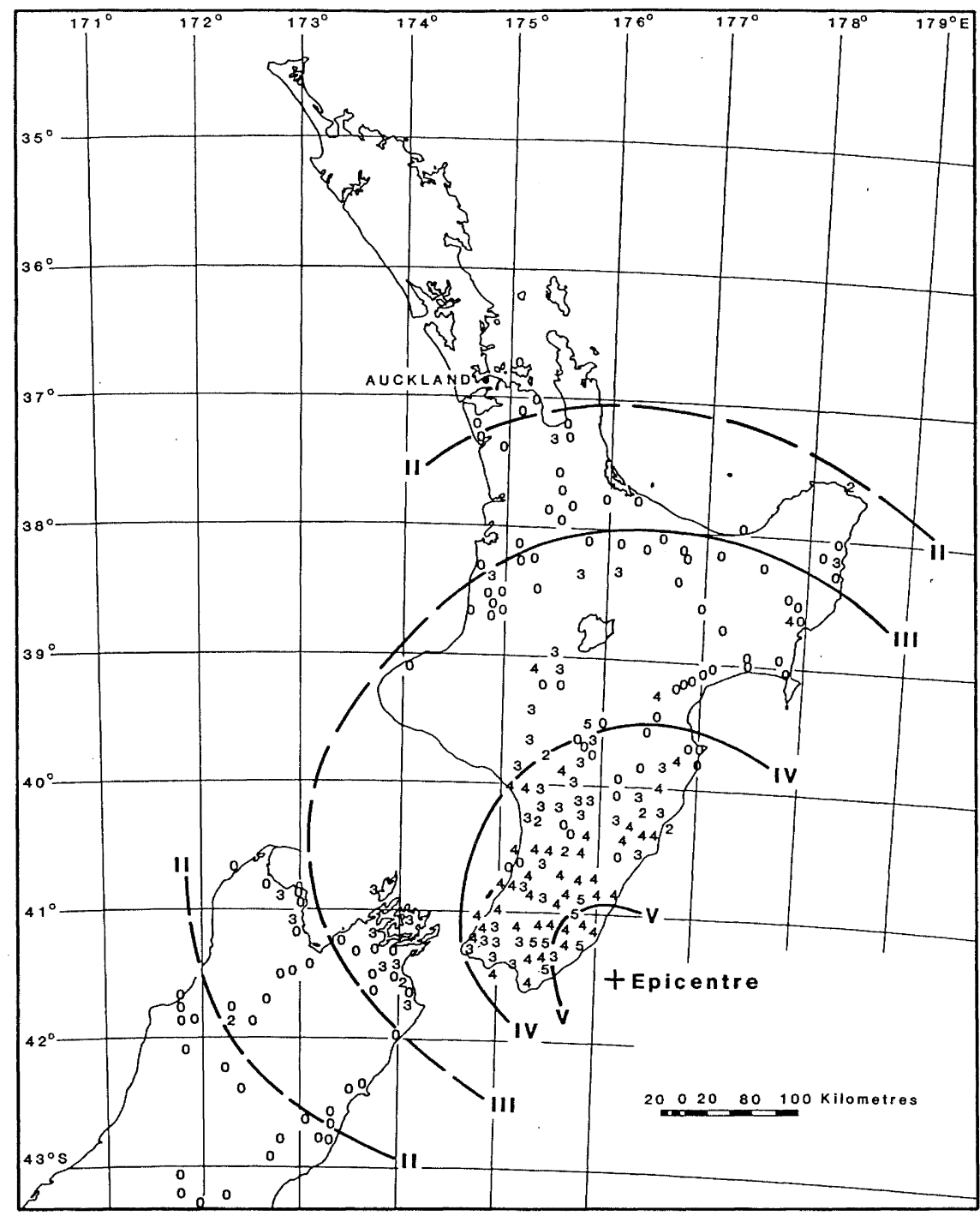

FIGURE 2 ISOSEISMAL MAP OF 1961 DEC 27 EARTHQUARE (FROM REF. 19), REJECTED FOR USE IN THIS STUDY BECAUSE CENTRE TOO FAR OFFSHORE FOR RELIABLE MEAN RADII TO BE DETERMINED.

approximate symmetry in the direction $\mathrm{N} 40^{\circ} \mathrm{E}$ (approx.). The missing eastern sections of the MM4 and MM5 isoseismals were interpolated following the shape of isoseismals MM6 to MM10 as shown.

These minimum requirements for using incomplete isoseismals resulted in the rejection of most of those event maps where the epicentre was offshore. For example the earthquake of 27 December 1961 (Figure 2) had its centre obviously too far offshore for determining half the isoseismal pattern. The 10 May 1962 earthquake (Figure 3) was a marginal case, there presumably being just under half of the isoseismals, as the epicentre (reasonably well-determined) was just offshore from the relatively straight coastline of the South Island. Two other marginal cases were the 30 January 1956 and 31 May 1977 earthquakes which were included despite having offshore epicentres. The reasons for their inclusion are discussed later (see Central Volcanic Zone, Section 3.1).

The above selection criteria resulted in 30 events with adequate isoseismal maps being chosen for the final regression analyses, the epicentral locations being plotted on Figure 4. The main characteristics of these events are listed in Table 1 , where the magnitudes are seen to range from $M_{T}=5.0$ to $\mathrm{M}_{\mathrm{S}}=7.8$. Ideally the magnitude used in equation (1) would be moment magnitude $\mathrm{M}_{W}$, but $M_{W}$ was available for only seven of the 30 events. Hence $M_{S}$ or $M_{L}$ was used as shown in Table 1. As discussed elsewhere [7], for shallow New Zealand events $M_{S}$ is better that $M_{I}$ as a measure of earthquake size for $M \geq$ 6. In practice I have adopted the larger of $M_{S}$ and $M_{L}$ where good values of both were available.

We note that the isoseismals on the unpublished maps (Events $1-10$ in Table 1) 


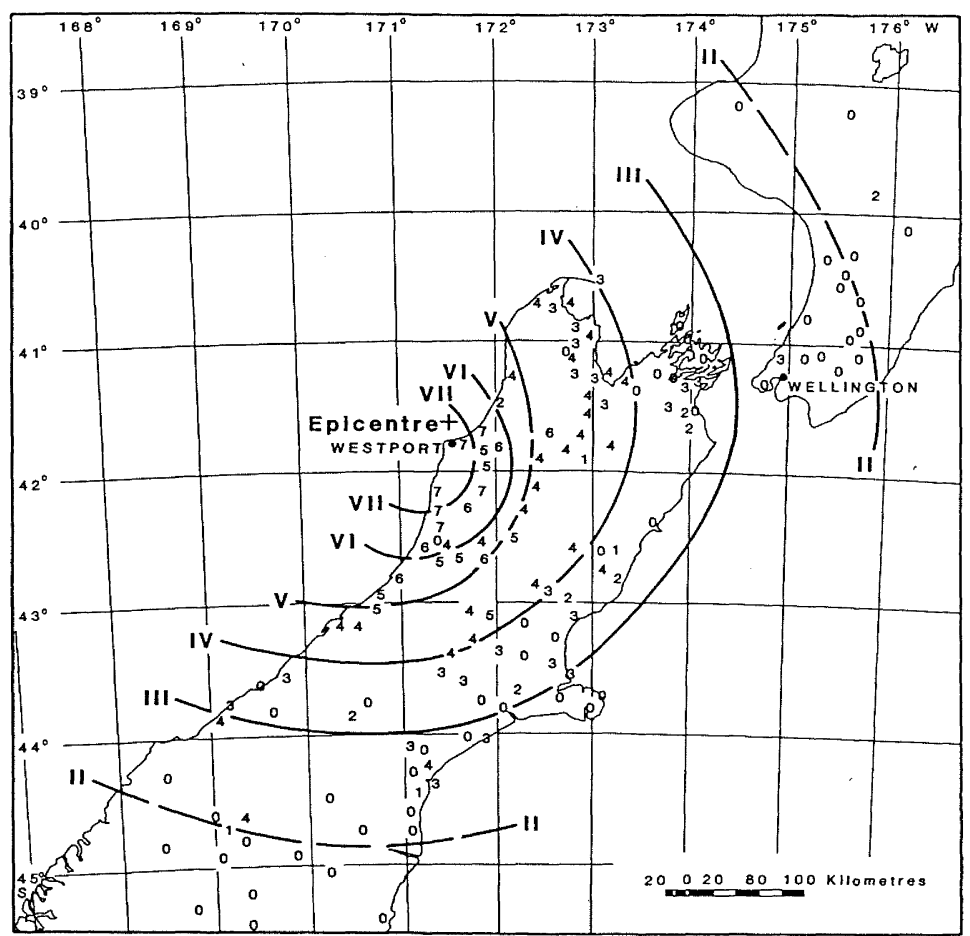

FIGURE 3 ISOSEISMAL MAP OF 1962 MAY 10 WESTPORT EARTHQUAKE (FROM REF. 20), WITH OFFSHORE CENTRE MARGINALLY ACCEPTABLE FOR DETERMINING RELIABLE MEAN RADII.

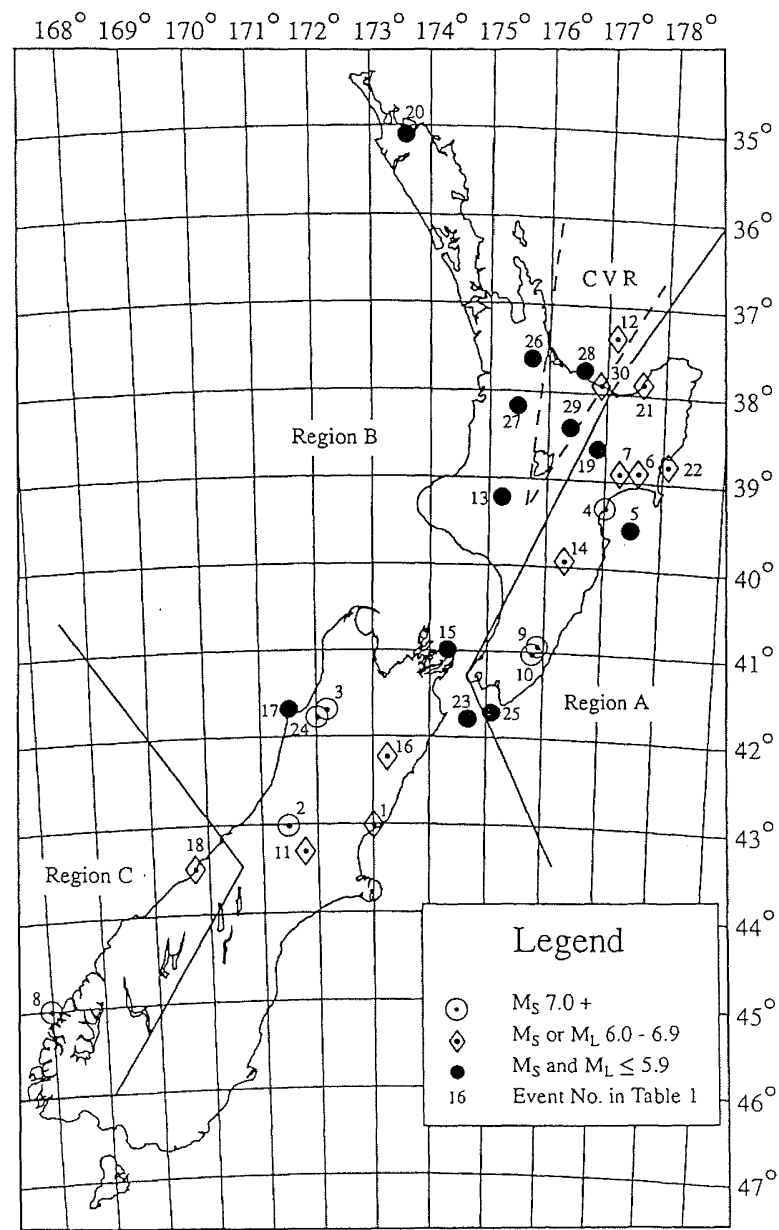

FIGURE 4 EPICENTRES OF EARTHOUAKE FROM TABLE 1 PLOTTED ON MAP SHOWING SMITH'S REGIONS A, B AND C AND ALSO THE CENTRAL VOLCANIC REGION (CVR). 
TABLE 1: NEW ZEALAND EARTHQUAKES CONSIDERED IN THIS STUDY

\begin{tabular}{|c|c|c|c|c|c|c|c|c|c|}
\hline \multirow{3}{*}{ No. } & \multirow{2}{*}{\multicolumn{3}{|c|}{ Date }} & \multicolumn{2}{|c|}{ Epicentre } & \multirow{2}{*}{$\begin{array}{c}\text { Focal } \\
\text { Depth } \\
(\mathrm{km})\end{array}$} & \multirow{2}{*}{$\begin{array}{c}\text { Earlier } \\
\text { M } \\
{[3]}\end{array}$} & \multirow{2}{*}{$\begin{array}{c}\text { Revised } \\
M_{L} \\
{[7]}\end{array}$} & \multirow{2}{*}{$\begin{array}{c}\mathrm{M}_{S} \\
{[6,7]}\end{array}$} \\
\hline & & & & & ${ }^{\circ} \mathrm{E}$ & & & & \\
\hline & 1922 & Dec 2 & 25 & 43 & 173 & $9-15$ & $6-7.5$ & & 6.4 \\
\hline 2 & 1929 & Mar 9 & 9 & 43 & $171 \frac{1}{2}$ & $<15$ & 6.9 & & 7.1 \\
\hline 3 & 1929 & Jun 1 & 16 & 41.7 & 172.2 & c. 15 & 7.6 & & 7.8 \\
\hline 4 & 1931 & Feb 2 & 2 & 39.3 & 177 & 30 & 7.8 & & 7.8 \\
\hline 5 & 1932 & May 5 & 5 & $39 \frac{1}{2}$ & $177 \frac{1}{2}$ & $\leq 30$ & $6-7.5$ & & 5.9 \\
\hline 6 & 1932 & Sep 1 & 15 & 38.9 & 177.6 & 30 & 7 & & 6.9 \\
\hline 7 & 1934 & $\operatorname{Mar} 1$ & 15 & 38.9 & 177.2 & $\leq 40$ & $6 \frac{1}{4}$ & & 6.4 \\
\hline 8 & 1938 & Dec 1 & 16 & 45 & 167 & $60 ?$ & 7.0 & & 7.0 \\
\hline 9 & 1942 & Jun 2 & 24 & 40.9 & 175.9 & 15 & 7.1 & & 7.2 \\
\hline 10 & 1942 & Aug 1 & 1 & 41.0 & 175.8 & 43 & 6 & & 7.0 \\
\hline 11 & 1946 & Jun 2 & 26 & 43.2 & 171.7 & $9-15$ & - & 6.2 & $6.4^{*}$ \\
\hline 12 & 1956 & $\operatorname{Jan} 3$ & 30 & 37.3 & 177.1 & 10 & 6.0 & 5.8 & $6.4^{*}$ \\
\hline 13 & 1957 & Feb 2 & 22 & 39.2 & 175.2 & $25-40$ & 5.5 & $5.6^{\star}$ & 4.9 \\
\hline 14 & 1958 & Jan 3 & 31 & 39.9 & 176.3 & $40 ?$ & 5.9 & $6.1^{\star}$ & 5.2 \\
\hline 15 & 1959 & May 2 & 22 & 41.0 & 174.3 & $40 ?$ & 6.0 & $5.8^{*}$ & 4.9 \\
\hline 16 & 1960 & Feb 2 & 21 & 42.3 & 173.1 & 50 & 6.4 & $6.2 *$ & 5.4 \\
\hline 17 & 1962 & May 1 & 10 & 41.7 & 171.5 & $<15$ & 5.9 & 5.8 & $5.9^{*}$ \\
\hline 18 & 1962 & oct 1 & 15 & 43.5 & 169.7 & $12-40$ & 6.1 & $6.2^{*}$ & 5.4 \\
\hline 19 & 1963 & Apr 1 & 12 & 38.6 & 176.8 & $20 ?$ & 6.0 & $5.9^{\star}$ & 5.7 \\
\hline 20 & 1963 & Dec 2 & 22 & 35.1 & 173.5 & $12 r$ & 5.2 & $5.0^{*}$ & 4.4 \\
\hline 21 & 1965 & Jun 1 & 15 & 37.9 & 177.5 & $65 \pm 5$ & 6.0 & $5.8^{*}$ & 5.3 \\
\hline 22 & 1966 & Mar 4 & 4 & 38.8 & 178.1 & 18 & 6.2 & $6.0^{\star}$ & 5.8 \\
\hline 23 & 1966 & Apr 2 & 23 & 41.8 & 174.7 & 20 & 6.0 & $5.8^{\star}$ & 5.6 \\
\hline 24 & 1968 & May 2 & 23 & 41.8 & 172.0 & C. 12 & 7.1 & 6.7 & $7.4^{*}$ \\
\hline 25 & 1968 & Nov 1 & 1 & 41.7 & 175.1 & $20-30$ & 5.5 & $5.4^{*}$ & 5.0 \\
\hline 26 & 1972 & Jan 8 & 8 & 37.6 & 175.7 & $5-12$ & 5.1 & $5.3^{\star}$ & 5.0 \\
\hline 27 & 1976 & Dec 5 & 5 & 38.2 & 175.5 & $3-5$ & - & 5.1 & - \\
\hline 28 & 1977 & May 3 & 31 & 37.8 & 176.8 & 10 & - & 5.4 & - \\
\hline 29 & 1983 & Dec 1 & 14 & 38.4 & 176.3 & 5 & - & $5.1^{*}$ & 4.6 \\
\hline 30 & 1987 & Mar 2 & 2 & 37.9 & 176.8 & 8 & - & 6.3 & $6.6^{*}$ \\
\hline
\end{tabular}

Note: *Value used in analysis 
have been derived by G A Eiby by converting maps originally prepared in the Rossi-Forel intensity scale. As such they are slightly approximate MM isoseismals, so comparison was made of the attenuation expressions obtained from Events 11-30 with those from the entire data set. No significant difference was found, either visually from comparative plots of the regression expressions or from the statistical t-test.

Because New zealand earthquakes originate at widely varying depths, so as to express attenuation in terms of a consistent measure of travel path length, it was decided to base the attenuation expression on distance from the centre of energy release. The depth of the latter is here termed the effective depth $h_{e}$, which may be approximated as the depth of the centroid of the rupture surface, defined generally (for upwards rupturing faults) simply as

$$
\mathrm{h}_{\mathrm{e}}=\mathrm{h}-0.5 \mathrm{w}_{\mathrm{z}} \mathrm{km}
$$

where $\mathrm{h}$ is the focal depth (from Table 1), and $w_{z}$ is the width of the vertical projection of the rupture surface. In a few cases it was assumed that $h_{e}=h$ [7]. Thus the radius $r$ in equation (1) becomes

$$
r=\left(r_{h}{ }^{2}+h_{e}\right)^{2} \frac{1}{2}
$$

where $r_{h}$ is the horizontal distance in kilometres from the isoseismal I to the centre of the isoseismal pattern.

The mean horizontal radii $r_{h}$ for all isoseismals are given in Table 2 , together with the preferred value of he for the 30 events used in the regression analyses. The sources of the depths and uncertainties have been further discussed elsewhere [7]. It is noted that the radius for MM10 for Event No. 3 given in Table 2 has been revised to about half that on the existing map due to a review of landslide evidence which had earlier been misinterpreted (G Hancox et al, DSIR, Lower Hutt, pers. comm. 1990). Values of epicentral intensity $I$ were included for a few events, where they could reasonably be inferred. These extra data were hoped to enrich the data set, but were found to have no substantive effect on the results, although their inclusion was preferred.

\section{RESULTS OF REGRESSION ANALYSES}

As described elsewhere [21], the coefficients in equation (1) were evaluated using a two-step multiple regression analysis of the type preferred by Joyner and Boore [22]. Analyses were made of various selections of the events described in Tables 1 and 2 , examining the significance of the following factors:

- source mechanism

- regional variation

The study of source mechanisms showed that the events having Normal and strike-slip fault mechanisms had no significant difference in attenuation behaviour, but that events with reverse fault mechanisms gave rise to intensities which were several percent higher than those of Normal and
Strike-slip events for the same magnitude and distance. This part of the study has been described in detail elsewhere [21], and produced the following mean regression curves:

$\underline{\mathrm{N}}+\mathrm{SS}$ fault mechanisms:

$I=2.18+1.411 \mathrm{M}-0.00439 \mathrm{r}-2.709 \log _{10} \mathrm{r}$

Reverse fault mechanisms:

$I=3.42+1.369 \mathrm{M}-0.00449 \mathrm{r}-3.037 \log _{10} \mathrm{r}$

These expressions were derived from data with magnitudes in the range $\mathrm{M}_{T}=5$ to $\mathrm{M}_{\mathrm{S}}=$ 7.8 and distances $r_{h} \leq 500 \mathrm{~km}$, and hence should be used with caution near either end of these ranges. The significance of regional variation and depth are considered in turn below.

\subsection{Regional variations in Attenuation}

The analyses of earthquakes in different parts of New Zealand carried out earlier by Smith [3, 4] suggested to him that attenuation was different in three regions $A, B$ and $C$ shown in Figure 4. Recently he has proposed [23] a further subdivision (not shown here) of the northern part of Region $B$ which includes the Central Volcanic Zone (CVR). As mentioned earlier Smith did not consider the depth or focal mechanism of the earthquakes in his data set. Let us now compare the attenuation of the events located in Regions $A$ and $B$, considering only Normal and Strike-slip mechanisms which have been shown elsewhere [21] to have virtually identical attenuation expressions.

For the regression analyses, for zone $A$ we use Events 7, 9, 14, 19, 25 and 30, which data set has a mean magnitude $M=6.3$ and $a$ mean depth $h_{e}=20 \mathrm{~km}$, while for zone $B$ we use Events 7, 11, 13, 15 and 26 which data set has a mean magnitude $M=6.0$ and mean depth $h_{e}=17 \mathrm{~km}$. Using the t-test it was found that difference between the resulting attenuation expressions for Zones $A$ and $B$ was not statistically significant.

Now turning to Smith's Region $c$, because it is in the mountainous south-west corner of the country (Figure 4) the inner isoseismals are poorly determined due to unpopulated mountainous terrain, and the outer isoseismals are very incomplete. Hence only two Events ( 8 and 18) were found which had maps with four isoseismals which satisfied the rules of adequacy described in section 2.0 (indeed Event No. 8 was only marginally acceptable). As two events do not enable us to obtain a regression expression of adequate robustness, it was decided instead to compare the data from these events with expressions derived from appropriate events chosen from the rest of the data set. As Event No. 8 has depth $h_{e}=60 \mathrm{~km}$, it was compared with a regression of a set of deeper events with depths $30 \leq h_{e} \leq 65$ (ie, Events $7,10,13-16,21)$, and Event No. 18 has depth $h_{e}=35 \mathrm{~km}$ so it was compared with a set of events with depths $22 \leq h_{e} \leq 43$ (ie, Events 7, 10, 13-15, 25).

In Figure 5 the mean regression curve drawn for $\left(M=7, h_{e}=60\right)$ is compared with the $I$, $r$ data points for Event No. 8 , and the curve for $\left(M=6.2, h_{e}=35\right)$ is compared with the 
TABLE 2: DISTANCE DATA USED IN REGRESSION ANALYSES

\begin{tabular}{|c|c|c|c|c|c|c|c|c|c|c|c|c|c|c|}
\hline \multirow{2}{*}{$\begin{array}{c}\text { Event } \\
\text { No. }\end{array}$} & \multirow{2}{*}{\multicolumn{2}{|c|}{ Date }} & \multicolumn{9}{|c|}{ Mean horizontal radius $(\mathrm{km})$ of isoseismals (MMI) } & \multirow{2}{*}{$\begin{array}{c}I_{0}(2) \\
\text { at } \\
r_{h}=2 \mathrm{~km}\end{array}$} & \multirow{2}{*}{$\begin{array}{c}\mathrm{h}_{\mathrm{e}} \\
(\mathrm{km})\end{array}$} & \multirow{2}{*}{$\begin{array}{l}\text { Region } \\
\text { (1) }\end{array}$} \\
\hline & & & 2 & 3 & 4 & 5 & 6 & 7 & 8 & 9 & 10 & & & \\
\hline 1 & 1922 & Dec 25 & & C. 440 & c. 280 & 176 & 89 & 45.6 & & & & & 9 & B \\
\hline 2 & 1929 & Mar 9 & & c. 397 & c. 321 & c. 199 & 102 & 51.1 & 26.8 & & & & 7 & B \\
\hline 3 & 1929 & Jun 16 & & & & & 236 & 153 & 94 & 61.6 & 28 & 10.5 & 8 & B \\
\hline 4 & 1931 & Feb 2 & & & & 273 & 195 & 106 & 64.9 & 45.3 & 28.5 & 10.5 & 17 & A \\
\hline 5 & 1932 & May 5 & & 289 & 156 & 102 & 48.4 & & & & & & 15 & A \\
\hline 6 & 1932 & Sep 15 & & 310 & 224 & 145 & 108 & 50 & 25.5 & 16.3 & 7.8 & & 17 & A \\
\hline 7 & 1934 & Mar 15 & & c. 350 & 182 & 90 & 46.5 & & & & & & 35 & A \\
\hline 8 & 1938 & Dec 16 & & C. 580 & c. 355 & 210 & 74 & & & & & & 60 & $C$ \\
\hline 9 & 1942 & Jun 24 & & 510 & 372 & 263 & 176 & 80 & & & & & 8 & A \\
\hline 10 & 1942 & Aug 1 & & C. $490 ?$ & 351 & 244 & 138 & 55.7 & & & & & 43 & $A$ \\
\hline 11 & 1946 & Jun 26 & & C. 327 & 226 & 161 & 57.4 & c. 27 & & & & 7.9 & 8 & B \\
\hline 12 & 1956 & $\operatorname{Jan} 30$ & C. 166 & C. 143 & c. 112 & C. 86 & & & & & & 9 & 5 & CVR \\
\hline 13 & 1957 & Feb 22 & & C. 128 & 86.4 & 52.3 & 20.6 & & & & & & 30 & B \\
\hline 14 & 1958 & Jan 31 & & C. 180 & 98 & 55.8 & 30.7 & 13 & & & & & 35 & A \\
\hline 15 & 1959 & May 22 & 264 & 190 & 136 & 81.4 & & & & & & & 35 & B \\
\hline 16 & 1960 & Feb 21 & c. 370 & C. 280 & c. 150 & 70 & 29 & & & & & & 50 & B \\
\hline
\end{tabular}


TABLE 2: DISTANCE DATA USED IN REGRESSION ANALYSES (Cont.)

\begin{tabular}{|c|c|c|c|c|c|c|c|c|c|c|c|c|c|c|}
\hline \multirow{2}{*}{$\begin{array}{c}\text { Event } \\
\text { No. }\end{array}$} & \multirow{2}{*}{\multicolumn{2}{|c|}{ Date }} & \multicolumn{9}{|c|}{ Mean horizontal radius $(\mathrm{km})$ of isoseismals (MMI) } & \multirow{2}{*}{$\begin{array}{c}\mathrm{I}_{0}(2) \\
\text { at } \\
\mathrm{r}_{\mathrm{h}}=2 \mathrm{~km}\end{array}$} & \multirow{2}{*}{$\begin{array}{c}\mathrm{h}_{\mathrm{e}} \\
(\mathrm{km})\end{array}$} & \multirow{2}{*}{$\begin{array}{l}\text { Region } \\
\text { (1) }\end{array}$} \\
\hline & & & 2 & 3 & 4 & 5 & 6 & 7 & 8 & 9 & 10 & & & \\
\hline 16 & 1960 & Feb 21 & c. 370 & c. 280 & c. 150 & 70 & 29 & & & & & & 50 & B \\
\hline 17 & 1962 & May 10 & 361 & 252 & 180 & 111 & 82 & 50 & & & & & 8 & B \\
\hline 18 & 1962 & Oct 15 & & 300 & 164 & 82.5 & 41.1 & & & & & & 35 & C \\
\hline 19 & 1963 & Apr 12 & 262 & 185 & 121 & 55.5 & 31 & & & & & & 17 & A \\
\hline 20 & 1963 & Dec 22 & & & 64.4 & 27.4 & 16 & 8.8 & & & & & 6 & B \\
\hline 21 & 1965 & 5 Jun 15 & c. 370 & 260 & 152 & 60 & & & & & & & 65 & A \\
\hline 22 & 1966 & 5 Mar 4 & & 168 & 122 & 70 & 42 & 15 & & & & & 18 & A \\
\hline 23 & 1966 & 5 Apr 23 & & 259 & 172 & 90 & 46.2 & & & & & & 17 & B \\
\hline 24 & 1968 & 3 May 23 & & & 413 & 261 & 138 & 82.9 & 42.3 & 22.3 & 9.3 & & 6 & B \\
\hline 25 & 1968 & 3 Nov 1 & & 264 & 168 & 59.5 & 20 & & & & & & 22 & A \\
\hline 26 & 1972 & Jan 8 & & & 110 & 60.5 & 18.6 & 7 & & & & & 7 & B \\
\hline 27 & 1976 & 5 Dec 5 & & & 65.9 & 48.3 & 32.8 & 16.5 & & & & 7.9 & 3 & B \\
\hline 28 & 1977 & May 31 & & & c. 52 & c. 36 & C. 20 & c. 10 & & & & 7.8 & 8 & CVR \\
\hline 29 & 1983 & Dec 14 & & & 28.1 & 16 & 8.8 & 5.4 & & & & 7.4 & 3 & CVR \\
\hline 30 & 1987 & Mar 2 & & & & 121 & 58.8 & 36.4 & 18.6 & 11.1 & & 9.8 & 4 & A \\
\hline
\end{tabular}




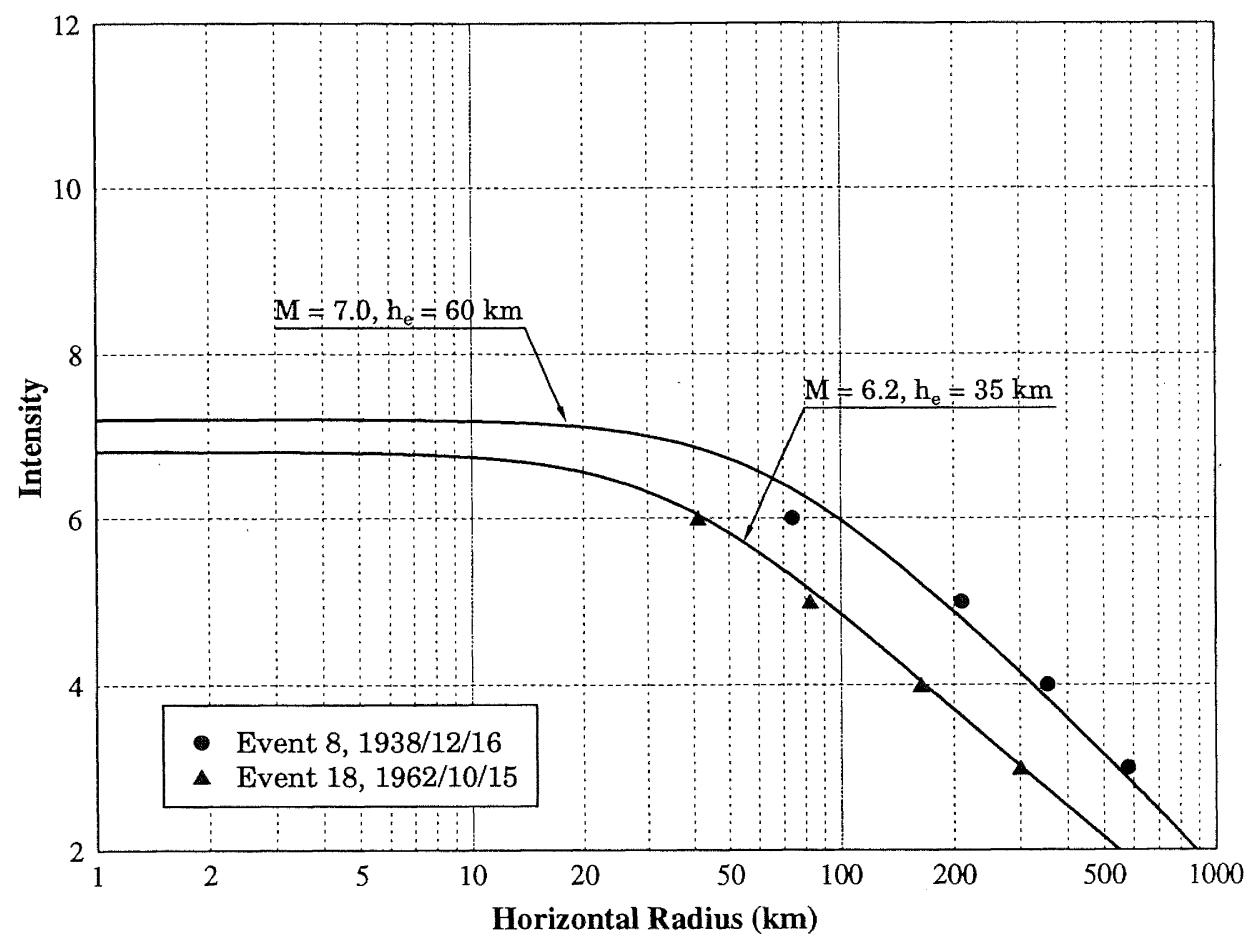

FIGURE 5 PLOTS OF ISOSEISMAL RADIUS DATA FOR EVENTS 8 AND 18 FROM REGION C (SEE FIGURE 4), COMPARED WITH MEAN REGRESSION MODELS OF CORRESPONDING $M, h$ DERIVED FROM APPROPRIATE DATA SET FROM THE REST OF THE COUNTRY (EXCEPT CVR).

I, r data points for Event No. 18. The curves and data points for both these events are obviously very similar. The isoseismal maps for both events also suggest that the epicentral intensity (at say $r_{h}=2 \mathrm{~km}$ ) would be about MM7, again the same as given by the regression curves. (These two events are also modelled well by equations (4) and (5) which are based on larger data sets.) Thus these two events suggest that the attenuation in Region $C$ is likely to be the same as the rest of the country. However, more evidence is required to enable firm conclusions to be drawn.

Next we turn our attention to the central Volcanic Region in the North Island (Figure $4)$. Here we again have few good data. Of the three events (Nos. 12, 28, 29) listed as CVR events, No. 12 and No. 28 both have offshore epicentres so that the isoseismal radii given in Table 2 are less certain than desired. As noted in section 2 these two events were marginal for adequacy, but were included in the hope that they might help give some indication of attenuation rates in the CVR. As noted in Table 2 the isoseismal data for Event 12 has been supplemented by including an estimated epicentral intensity Io $\approx 9$ at $r_{h}=2 \mathrm{~km}$ in an attempt to improve the analysis. The Edgecumbe earthquake (Event 30) was a marginal fourth contender for CVR membership, as it was located on its boundary. However it was excluded from the CVR and has been shown elsewhere [21] to conform well to the attenuation pattern of the rest of the country.

A regression analysis of the data from the three events $(12,28,29)$ was carried out, but gave unsatisfactory results, both with and without the inclusion of the $I_{0}$ data point for events 28 and 29 . So, as with Region $C$ above, the I, $r$ data of the three events were compared with attenuation curves of appropriate $M$ and $h_{e}$ derived data from shallow N+SS events from the rest of the country, equation (4). The results of this comparison were not very conclusive. Event No. 28 data points matched the model curve quite well while Event No. 29 data points (the most reliable of the three events) indicated a more rapid rate of attenuation than that given by the model curve (Figure 6). This difference in attenuation rate from the rest of the country is likely to be due to anelastic attenuation, and is of a similar value to that found earlier for the CVR by Haines [24]. It is clear however that more data is required before the intensity attenuation rate in this region can be properly assessed.

\subsection{Depth and Magnitude Effects}

The effects of magnitude and depth changes on attenuation are illustrated by plotting curves for events of two depths for both $M$ $=5$ and $\mathrm{M}=7.5$, using the expression for $N+S S$ events, equation (4). The increase in magnitude from $M=5$ to $M=7.5$ causes an increase in intensity of 3-4 units over the full distance range shown on Figure 8 . We also see that an increase in depth from $h_{0}=$ 8 to $45 \mathrm{~km}$ decreases the central intensity by approximately 2 units from MM10 to MM8 for $M=7.5$ events, denoting a change from a strongly damaging to a modestly damaging event. 


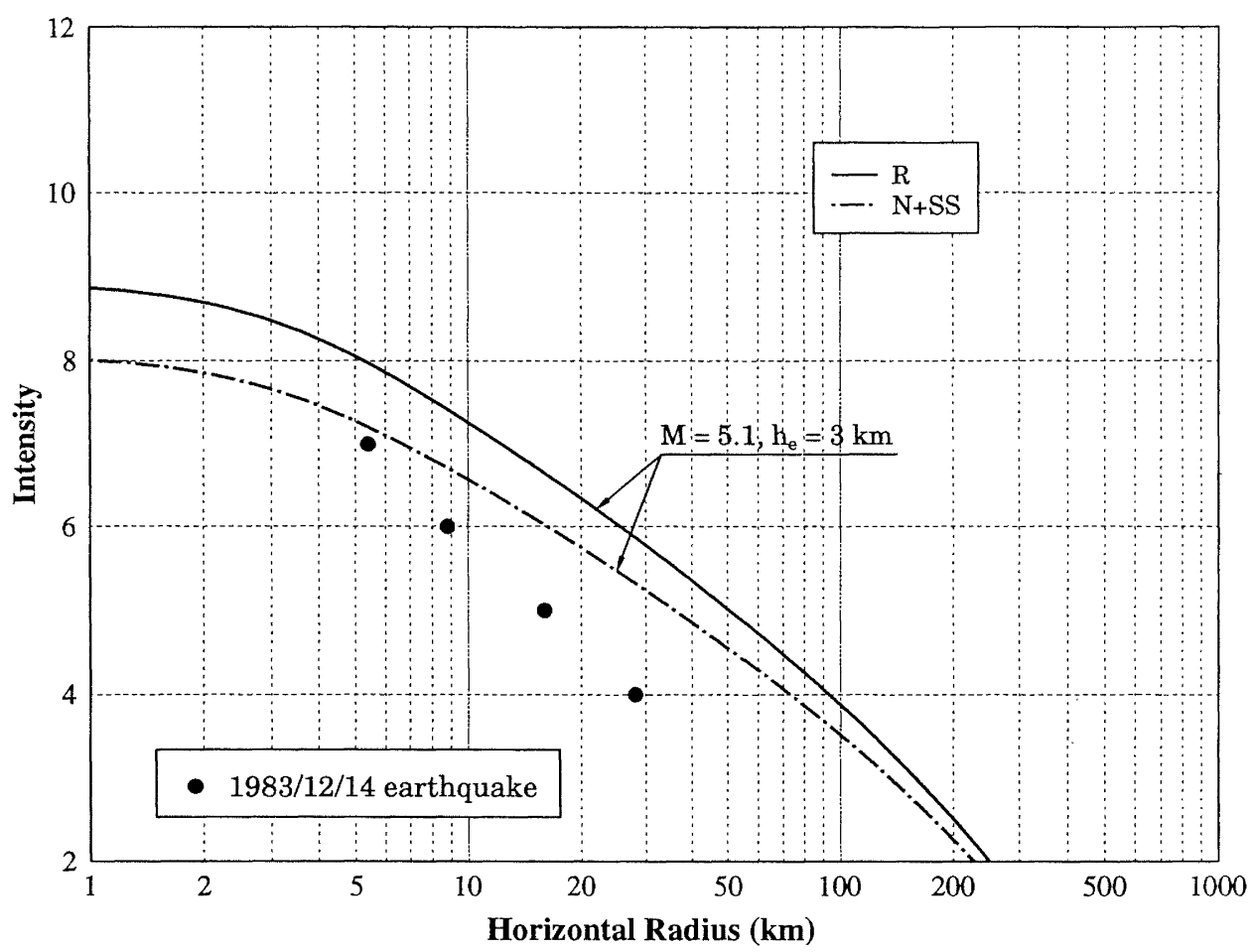

FIGURE 6 PLOT OF ISOSEISMAL RADIUS DATA FOR EVENT 29 FROM THE CVR, COMPARED WITH MEAN REGRESSION MODEL OF CORRESPONDING $M, h_{e}$ DERIVED FROM APPROPRIATE DATA SET FROM THE REST OF THE COUNTRY.

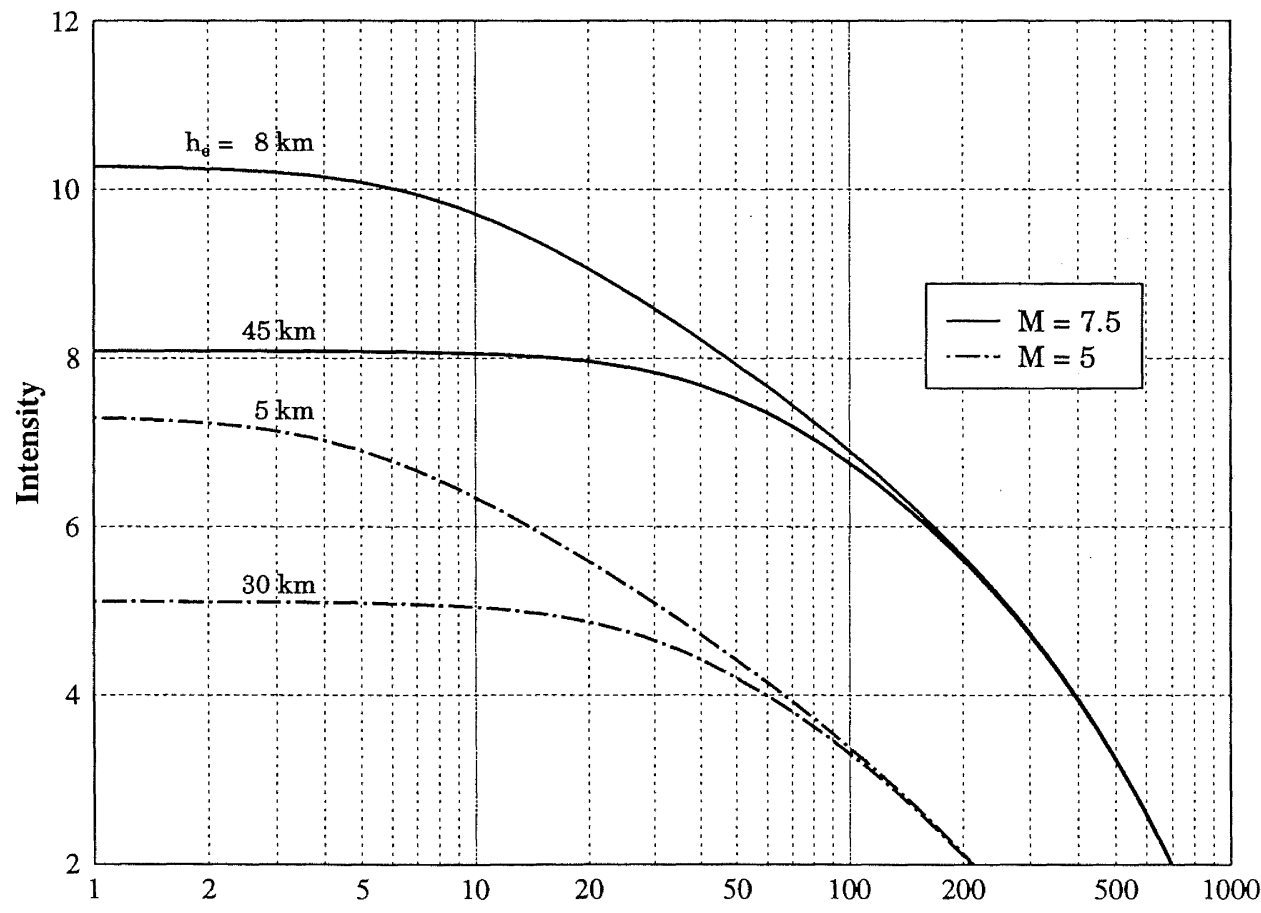

FIGURE 7 PLOT OF MEAN REGRESSION CURVES FOR N+SS EVENTS OF M $=5$ AND 7.5 , SHOWING EFFECT OF DIFFERENCES IN DEPTH. 


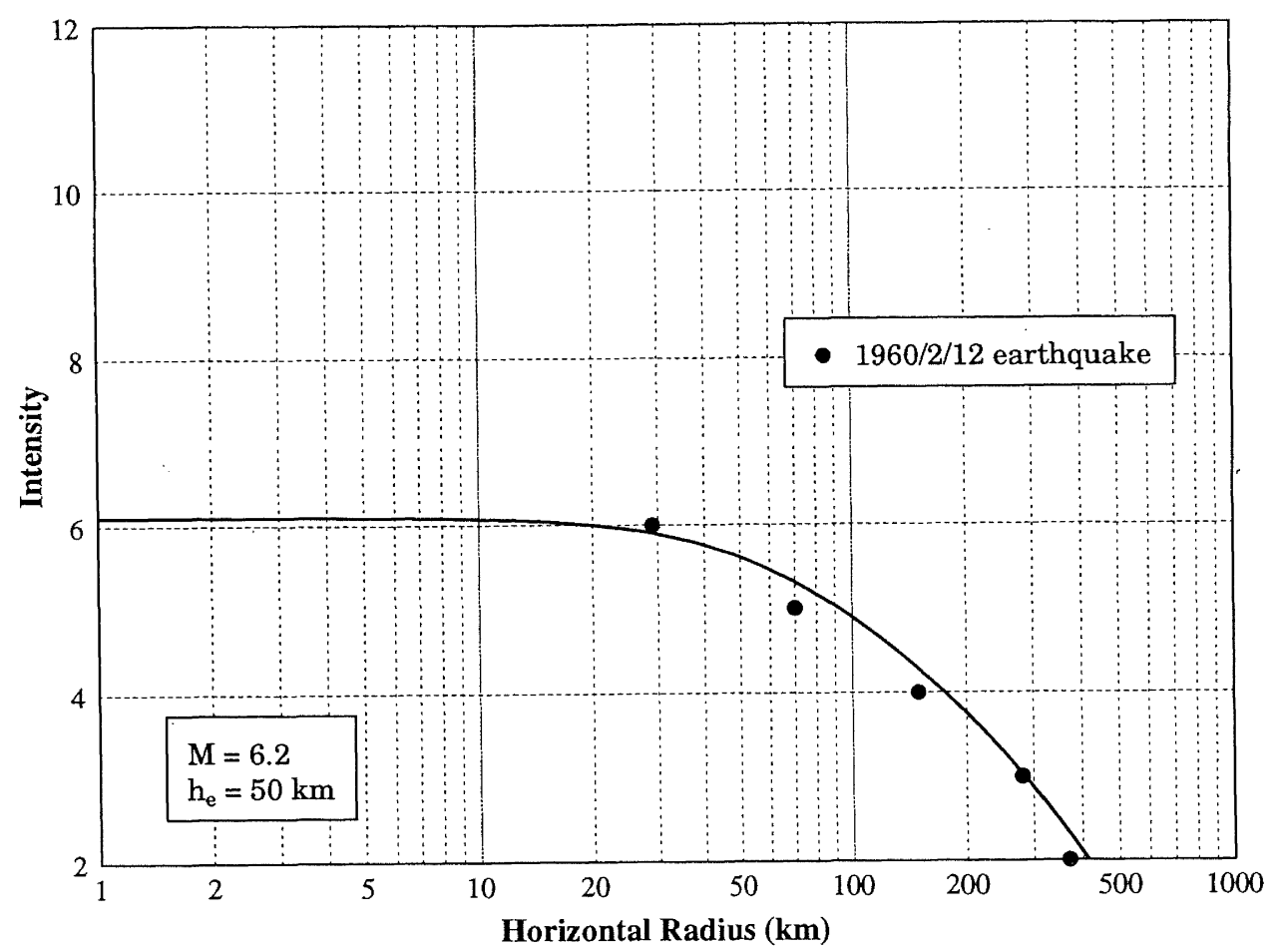

FIGURE 8 PLOT OF ISOSEISMAL RADIUS DATA OF EVENT 16 WHICH WAS RELATIVELY DEEP $\left(h_{e}=50 \mathrm{RM}\right)$ AND OF SS SOURCE MECHANISM, SHOWING CLOSE COMPARISON WITH APPROPRIATE MEAN REGRESSION MODEL.

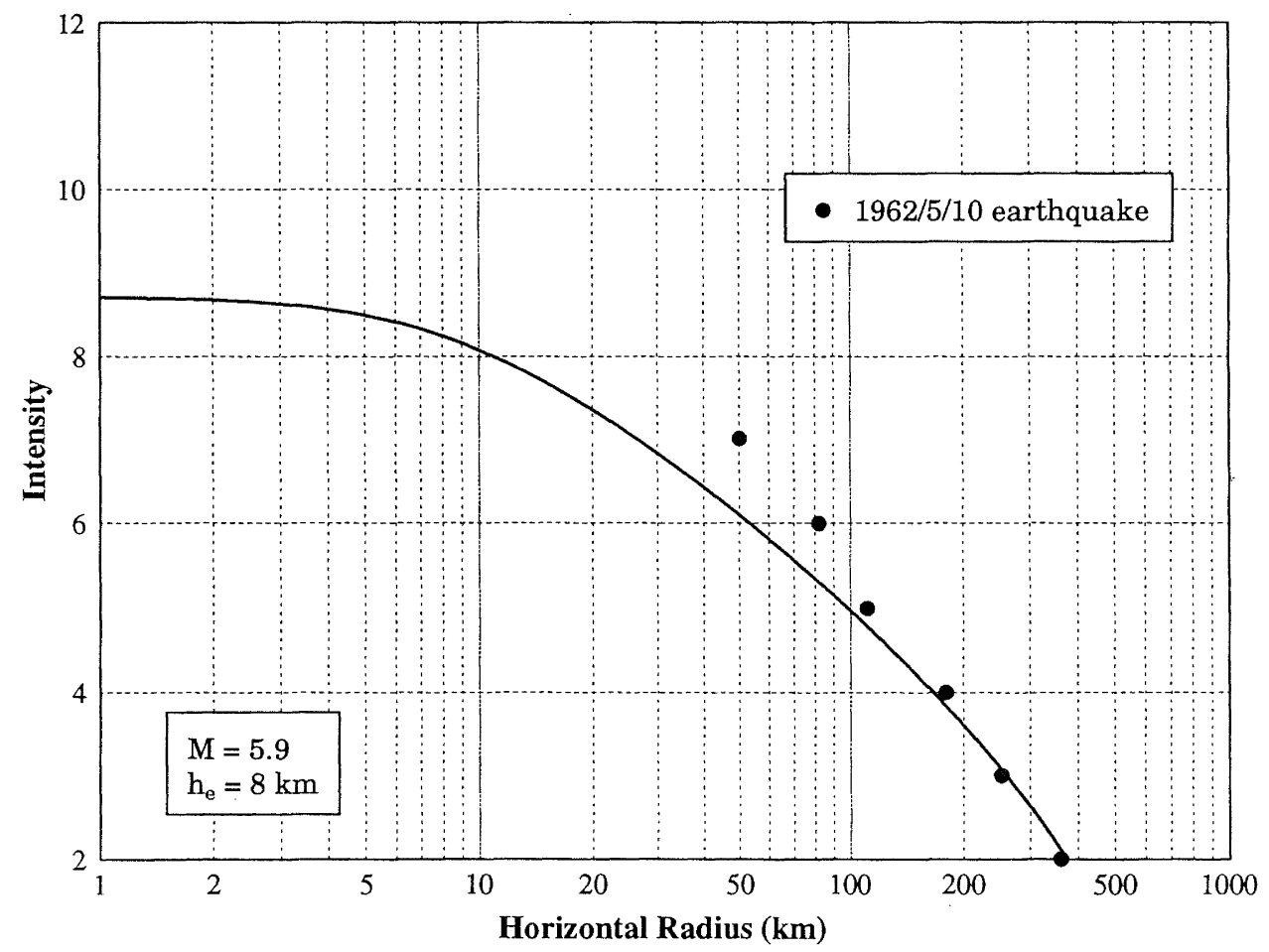

FIGURE 9 PLOT OF ISOSEISMAL RADIUS DATA OF EVENT 17 (FIGURE 3) OF REVERSE FAULT MECHANISM, COMPARED WITH APPROPRIATE MEAN REGRESSION MODEL. OFFSHORE CENTRE OF THIS EVENT MAY CONTRIBUTE TO THE SCATTER OF DATA POINTS AT MMG AND MM7. 
Figure 7 shows that an average shallow magnitude 5 event (N or SS source mechanism) is at the lower limit of engineering interest, having a central intensity of only MM7. If such an event was of he $=30 \mathrm{~km}$ the maximum intensity on average would be only MM5.

\subsection{Comparison of Event Data with Reqression Curves}

In Figure 8 we plot the isoseismal radii for the relatively deep Strike-slip Event No. 16 with its appropriate mean curve for $M=6.2$ and $h_{e}=50 \mathrm{~km}$ derived from equation (4). In this example, we see that the model and the five data points match very well, and note the maximum local intensity reported in this earthquake was MM6 which also conforms with the central intensity of the model. As seen on Figure 4 this event was centred well inland and the centre of the isoseismals was well determined. By contrast we will now consider the 1962 westport earthquake which had an offshore fault rupture (Figure 3 ) and was considered to be only marginally acceptable for use in the regression analysis (as discussed in section 2). As seen in Figure 9 the outer four isoseismal data points lie very close to the mean regression curve for this reverse fault event derived from equation (5) using $M=$ 5.9 and $\mathrm{h}_{\mathrm{e}}=8 \mathrm{~km}$, but the two inner isoseismals (MM6, MM7) show moderate deviations from the mean line. As may be seen from Figure 3 these inner isoseismals are susceptible to relatively large errors when estimating their mean radii, because their "true" shape is known for perhaps only $100-120^{\circ}$ of arc about the real but uncertain centre (instead of the desired minimum of $\left.180^{\circ}\right)$.

We now compare the isoseismal data for an event with uncertain fault mechanism, ie, the 1976 Korakonui earthquake (Event 27) of $\mathrm{M}=5.1$ and $\mathrm{h}_{\mathrm{e}}=3 \mathrm{~km}$. The earthquake was thought equally likely to be of Reverse or Strike-slip fault mechanism, so in Figure 10 we compare the appropriate mean curves from equations (4) and (5) with the data points. At the time of its occurrence the intensities of this earthquake were thought to be anomalously high [14]. However, with the benefit of our new attenuation relationships, it is evident from Figure 10 that this would not be the case if the event had a reverse fault mechanism. We note that the isoseismal map [14] had a small isoseismal for MM8 (of $c .5 \mathrm{~km}$ radius) but which was very much off centre. It was evidently a local microzoning effect and not part of the main attenuation pattern, and hence is not plotted in the figure.

\subsection{Comparison of Attenuation in New zealand and Turkey}

Turkey is a tectonic region which, like New zealand, is dominated by strike-slip faulting. Ambraseys $[8,9]$ had studied the attenuation of intensity in Turkey for events with focal depths $\leq 15 \mathrm{~km}$, using the same form of expression used here. The Turkish intensity data is in the MSK scale which conveniently is essentially directly equivalent to the MMI scale. Inverting Ambraseys' equation (1) for Turkey [8] we have

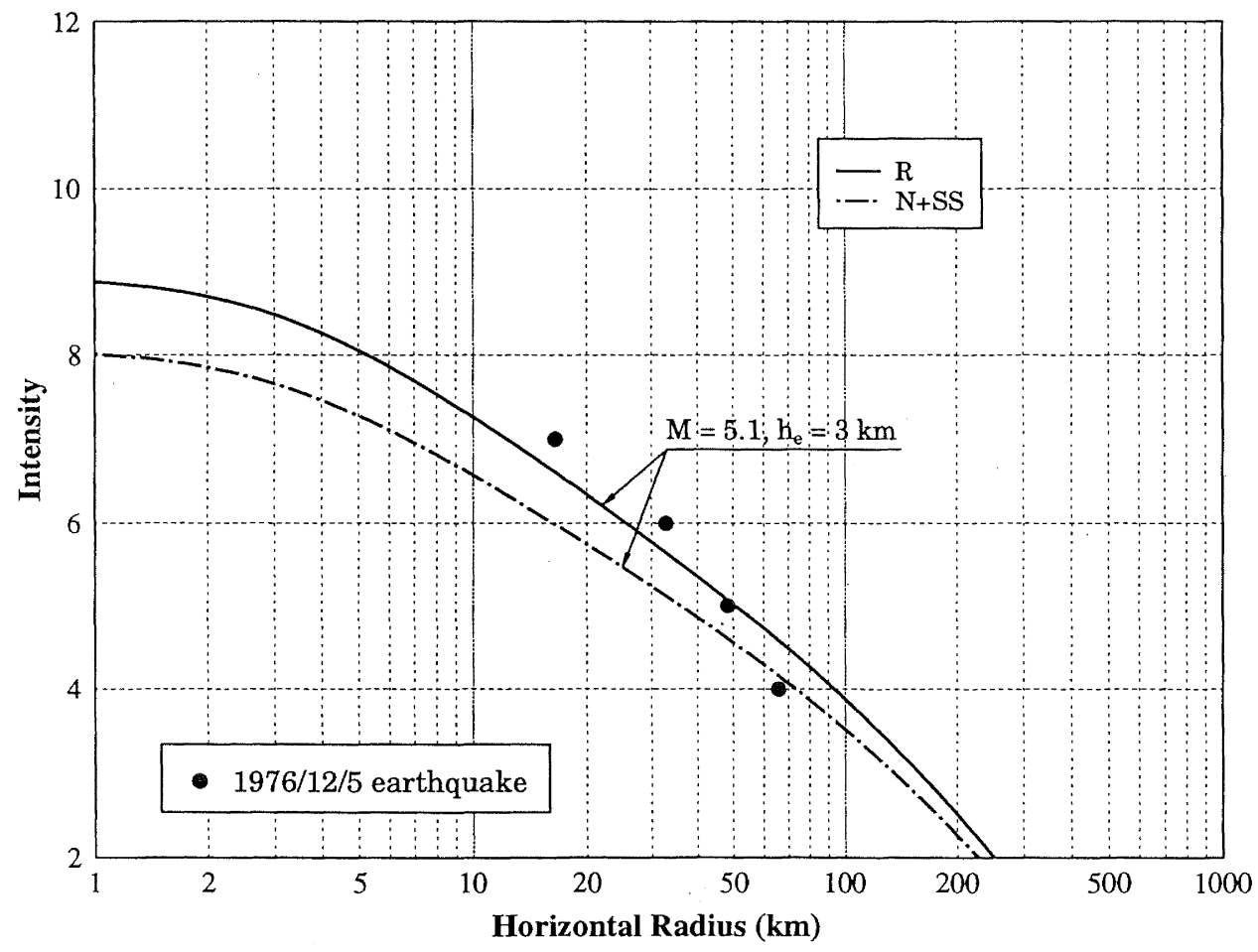

FIGURE 10 PLOT OF ISOSEISMAL RADIUS DATA OF 1976 RORAKONUI EARTHQUAKE (EVENT 26) OF UNCERTAIN FAULT MECHANISM, COMPARED WITH MEAN REGRESSION CURVES FOR N+SS AND REVERSE SOURCE MECHANISMS. 


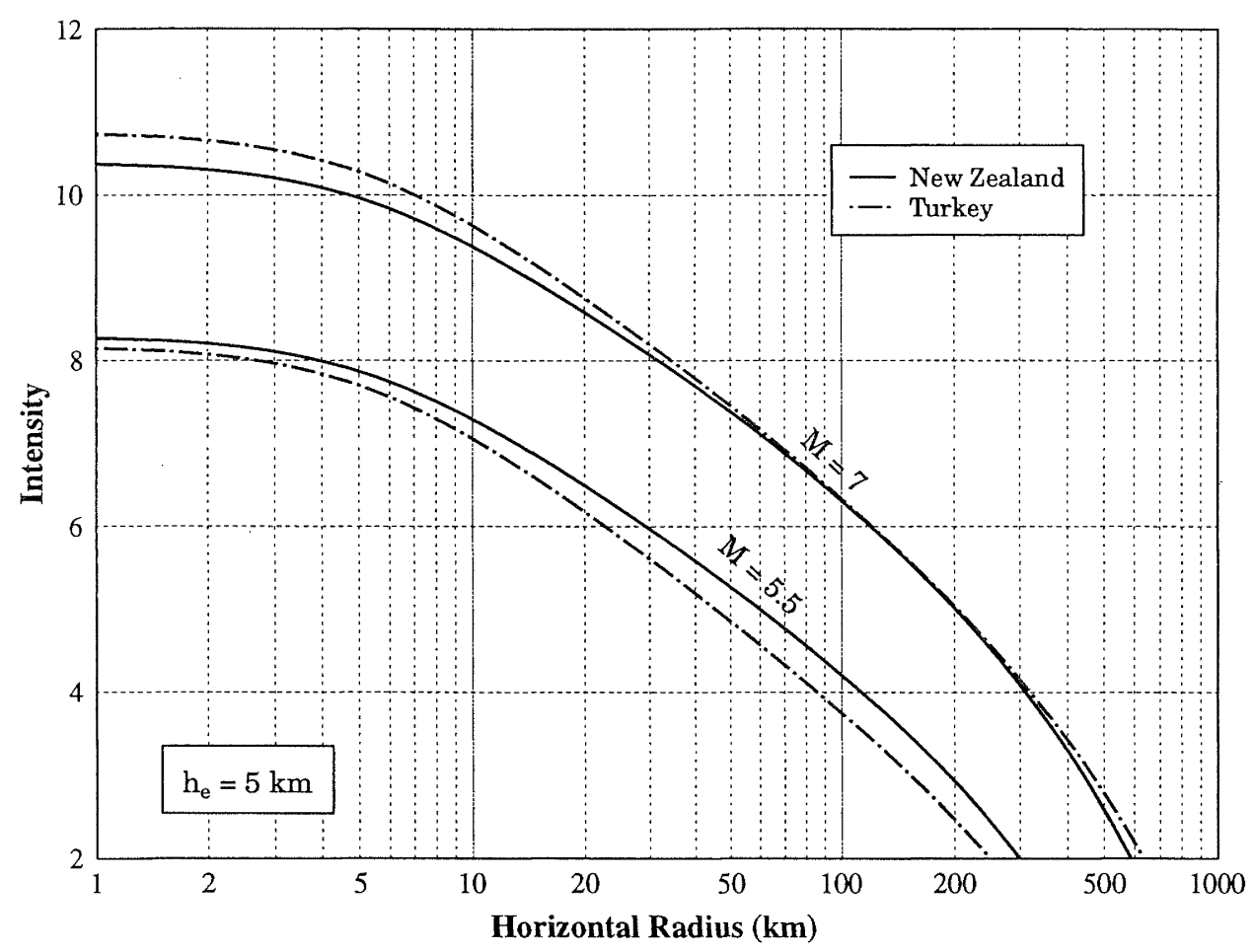

FIGURE 11 ATTENUATION CURVES SHOWING CLOSE SIMILARITY OF RESULTS FOR NEW ZEALAND AND TURKEY FOR SHALLOW EVENTS OF $M=5.5-7.0$.

As equation (6) includes events of all source mechanisms, to obtain a quick and reasonably accurate comparison with attenuation in New Zealand let us assume that one third of the Turkish events were of predominantly reverse fault type. The New Zealand expression for this mixture of source mechanisms was found (approximately) by merging equations (4) and (5) weighted $2 / 3$ and $1 / 3$ respectively, resulting in

$$
I=2.59+1.40 \mathrm{M}-0.0044 \mathrm{r}-2.82 \log _{10} \mathrm{r}
$$

Equations (6) and (7) should thus represent reasonably comparable data bases from Turkey and New Zealand, and attenuation curves for $\mathrm{M}=5.5$ and 7.0 with $\mathrm{h}_{\mathrm{e}}=5 \mathrm{~km}$ are plotted for both regions in Figure $11\left(\mathrm{~h}_{\mathrm{e}}=5 \mathrm{~km}\right.$ corresponds approximately to the mean effective depth of the focal depth range for Ambraseys' Turkish data noted above). It is clear that Figure 11 shows that attenuation in New Zealand and Turkey is very similar, which in view of the similar geological regimes, gives mutual support to these two independent studies.

\section{ISOSEISMAL SHAPE}

In the 1970's smith $[3,4]$ examined the shapes of the isoseismals which he approximated to ellipses, and found values for the ratio $a / b$ where $a$ and $b$ are the semi-diameters of the major and minor axes respectively. He plotted the geographical distribution of these ratios. I have made a preliminary examination of the isoseismal shapes and find that no convincing systematic pattern may be readily described. Further study of this factor is proposed for a later date.

\section{ESTIMATES OF MAGNITUDE FROM ISOSEISMAL DATA}

For early earthquakes for which no instrumental magnitude is available, estimates of magnitude may be made if reasonable isoseismal maps are available. This is done simply by inverting the appropriate attenuation expression such as equation (4) or (5) above, and finding $\mathrm{M}_{I}$ for the I, pair of each isoseismal, then finding the average $M$ from all $M_{I}$ available for the event concerned.

I have applied this procedure to two large 19th century earthquakes for which isoseismal maps have been prepared. These were the Marlborough earthquake of 1848 October $16 \quad[25,26]$ and the Wairarapa earthquake of 1855 January 23 [27]. Taking the depth and source mechanisms into account my best estimates of the magnitudes of these events are $M \approx 7.9$ and 8.4 respectively. These values are considerably greater than earlier magnitude estimates as shown for comparison in Table 3.

Such estimates of the magnitudes of these two earthquakes should be treated with caution, because (a) they are derived from isoseismal maps based on sparse data in the early days of European settlement of New Zealand, and (b) they involve extrapolation from the magnitude range of the data on which equations (4) and (5) were based. Also given in Table 3 is the estimated moment magnitude $\mathrm{Mw}=8.2$ obtained from dislocation modelling studies [28] of regional uplift during the 1855 Wairarapa event. This estimate also has to be treated with caution because of uncertainties in the uplift data available from the early period. 
TABLE 3. MAGNITUDE ESTIMATES OF TWO LARGE

PRE-INSTRUMENTAL NEW ZEALAND EARTHQUAKES

\begin{tabular}{|c|c|c|c|}
\hline Event & Earlier Estimates & This study & $\begin{array}{c}\text { Dislocation model } \\
(3)\end{array}$ \\
\hline \hline 1848 Oct 16 & $7.1^{(1)}$ & 7.9 & \\
1955 Jan 23 & $8.0^{(2)}$ & 8.4 & 8.2 \\
\hline
\end{tabular}

Notes: (1) Eiby $[25,26]$

(2) Eiby [27]

(3) Darby and Beanland [28]

\section{CONCLUSIONS}

This study involved the use of a completely revised set of magnitudes for all the events in the data base, and included studies of the effects of depth, source mechanism and regional location. The attenuation expression used was of the form

$$
I=a+b M+c r+d \log _{10} r
$$

where $r$ is the slope distance from the isoseismal to a point below the centre of the isoseismal pattern at the effective depth $h_{e}$ of the centroid of the fault rupture surfaces. The conclusions reached were as follows:

1 The findings of this study completely revise the results of earlier studies.

2 Depth was shown to have a major influence on the resulting attenuation expressions, which worked well for all events in the data set which had events of effective depths $h_{e} \leq 65 \mathrm{~km}$.

3 The comparison of attenuation in different regions found no difference in the attenuation in Smith's $[3,4,23]$ Regions A, B and D, while Smith's Region $C$ and the Central Volcanic Region need more data before their attenuation characteristics can be properly established.

4 The intensities of the 1976 Korakonui earthquake do not appear to have been anomalously high as reported at the time.

5 The attenuation of intensity in New zealand was found to be very similar to that of Turkey, the two regions being dominated by strike-slip faulting.

6 The attenuation expressions found in this study may be inverted to estimate the magnitude of early earthquakes for which instrumental magnitudes are unavailable. Estimates made in this way gave $M \approx 7.9$ for the 1848 Marlborough earthquake and $M \approx 8.4$ for the 1855 Wairarapa earthquake. These estimates involve some extrapolation from the data base, but are markedly larger than previous estimates made in the same way.

\section{ACKNOWLEDGEMENTS}

The author gratefully acknowledges the friendly advice and assistance given by various people at different stages of the study. I note especially $\mathrm{N}$ Ambraseys of Imperial College, London for general advice and encouragement, and DSIR colleagues in New Zealand particularly K Berryman, G Eiby, $M$ Reyners, and $E$ Smith for geological/seismological data and insights, and $W$ D Smith for providing me with a good starting point.

In addition I thank my colleague $J$ Babor who developed a user-friendly one-step regression analysis program; D Rhoades whose expertise in statistical analysis and assistance with the two-step regression analysis were invaluable; and $S$ sritharan and $M$ McDonald who prepared the illustrations. Also I wish to thank G McVerry for his constructive in-house review.

\section{REFERENCES}

1 G A EIBY, "The Modified Mercalli Scale of earthquake intensity and its use in New Zealand", NZ Jnl. of Geology and Geophysics, Vol. 9, pp122-129, 1966.

2 G A EIBY, "Intensities a strictly subjective view", Bull. NZ National Soc. for Earthquake Eng., Vol. 9, pp181-183, 1976.

3 W D SMITH, "Statistical estimates of the likelihood of earthquake shaking throughout New Zealand", Bull. NZ National Soc. for Earthquake Eng., Vol. 9, pp213-221, 1976.

4 W D SMITH, "Spatial distribution of felt intensities for New Zealand earthquakes", NZ Jnl. of Geology and Geophysics, Vol. 21, 293-311, 1978.

5 P WALLEY, "The estimation of earthquake risk in New Zealand", Tech. Report No 49, NZDSIR, Applied Mathematics Division, 1976. 
6 D J DOWRICK and E G C SMITH, "Surface wave magnitudes of some New Zealand earthquakes 1901-1988", Bull. NZ National Soc. for Earthquake Eng., Vol. 23, pp198-210, 1990.

7 D J DOWRICK, "Magnitude reassessment of New Zealand earthquakes", Earthquake Eng. Struct. Dynamics, Vol. 20, pp577-596, 1991.

$8 \quad \mathrm{~N}$ N AMBRASEYS, "Engineering seismology ", Earthquake Eng. Struct. Dynamics, Vol. 17, pp1-105, 1988.

$9 \mathrm{~N} N$ AMBRASEYS, "Temporary seismic quiescence: SE Turkey", Earthquake Eng. struct. Dynamics, Vol. 18, pp311-331, 1989 .

10 W B JOYNER and D M BOORE, "Peak ground horizontal acceleration and velocity from strong-motion records including records from the 1979 Imperial Valley, California, earthquake", Bull. Seism. Soc. Amer., Vol. 71, pp1993-2009, 1981.

11 G A EIBY, "Lake Coleridge earthquakes of 1946", Bull. NZ National Soc. for Earthquake Eng., Vol.23, pp150-158, 1990 .

12 G A EIBY, "Earthquakes in Northland", New Zealand Engineering, Vol. 19, pp125-128, 1964 .

$13 \mathrm{R}$ D ADAMS, $M$ G MUIR and $R \mathrm{~J}$ KEAN, "Te Aroha earthquake, 9 January 1972", Bull. NZ Soc. for Earthquake Eng., Vol. 5, pp54-58, 1972 .

14 G A EIBY, "Anomalous intensities due to the Korakanui earthquake, 5 December 1976", Bull. NZ National Soc. for Earthquake Eng., Vol. 10, pp167-169, 1977.

15 W P RICHARDSON, "The Matata earthquake of 1977 May 31: a recent event near Edgecumbe, Bay of Plenty, New Zealand", NZ Jnl. Geology and Geophysics, Vol. 32, pp17-30, 1989 .

16 E G C SMITH, B J SCOTT and J M LATTER, "The Waiotapu earthquake of 1983, December 14", Bull. NZ National Soc. for Earthquake Eng., Vol. 17, pp272-279, 1984 .

$17 \mathrm{M}$ A LOWRY, S C EDE and J A HARRIS, "Assessment of seismic intensities resulting from the 1987 Edgecumbe earthquake, New zealand, and implications for modernising the intensity scale", NZ Jnl. Geology and Geophysics, Vol. 32, pp145-154, 1989.
18 --, New Zealand Seismological Report, Seismological observatory Bulletin E-147, NZDSIR, Geophysics Division, 1968 .

19 --, New Zealand Seismological Report, Seismological observatory Bulletin $\mathrm{E}-142,1961$.

20 --, New Zealand Seismological Report, Seismological observatory Bulletin E-143, 1962 .

21 D J DOWRICK, "Attenuation of Modified Mercalli intensity in New Zealand", Earthquake Eng. Struct. Dyn. (in press).

22 W B JOYNER and D M BOORE, "Measurement, characterization and prediction of strong ground motion", pp 43-102 of "Earthquake Engineering and Soil Dynamics II - Recent Advances in Ground Motion Evaluation", Geotechnical special Publication No. 20, American Society of Civil Engineers, New York, 1988.

23 W D SMITH, "Earthquake hazard in New Zealand: Some implications of the Edgecumbe earthquake, March 1987", Bull. NZ National Soc. for Earthquake Eng., Vol. 23, pp211-219, 1990.

24 A J HAINES, "A local magnitude scale for New Zealand earthquakes", Bull. Seism. Soc. of America, Vol. 71, pp275-294, 1981.

25 G A EIBY, "A descriptive catalogue of New Zealand earthquakes, Part 2 - shocks felt from 1846 to $1854 "$, NZ Jnl. Geol and Geophysics, Vol. 16, pp857-907, 1973 .

26 G A EIBY, "The Marlborough Earthquakes of 1848", NZDSIR Bulletin 225, 1980.

27 G A EIBY, "An annotated list of New Zealand earthquakes, 1460-1965", NZ Jnl. Geol Geophysics, Vol. 11, pp630-647, 1968 .

28 D J DARBY and $S$ BEANLAND, "Possible source models for the 1855 Wairarapa earthquake, New Zealand", (in prep 1991). 